\title{
Dayak Onions (Eleutherine bulbosa (Mill.) Urb.) Bulbs Extracts Reduces Blood Pressure of Hypoestrogen Model Rats by Controlling Lipids Profile
}

\author{
El Extracto de Bulbos de Cebollas Dayak (Eleutherine bulbosa (Mill.) Urb.) Reduce la \\ Presión Sanguínea en un Modelo Hipoestrogénico en Ratas Controlando el Perfil Lipídico
}

\author{
Anton Bahtiar \& Delvika Yessi Chumala
}

BAHTIAR, A. \& CHUMALA, D. Y. Dayak onions (Eleutherine bulbosa (Mill.)Urb.) bulbs extracts reduces blood pressure of hypoestrogen model rats by controlling lipids profile. Int. J. Morphol., 36(3):1016-1021, 2018.

SUMMARY: To determine the effects of $70 \%$ ethanolic extract of Eleutherine bulbosa (Mill.) L. bulbs contained naphtoquinone in blood pressure and lipids profile level of ovariectomized rats. Thin layer chromatography was performed to analyze the content of the Eleutherine bulbosa (Mill.) bulbs extracts using Chloroform : Methanol (7:1) as eluent. This study used white female Sprague-Dawley rats which were divided into 6 groups: SHAM and OVX, both given $0.5 \%$ carboxymethyl cellulose; the positive control group that was given tamoxifen $(0.36 \mathrm{mg} / 200 \mathrm{~g} \mathrm{~B} . \mathrm{W}$.); the three various of doses of extract namely dose 1,2 , and 3 that were given 8,12 , and $18 \mathrm{mg} / 200$ g BW respectively on day 29 until 50. All groups were ovariectomized on day 1, except sham group. Measurement of blood pressure were performed on the day before ovariectomy using non-invasive tool CODA ${ }^{\circledR}$; and on the second, third, and fourth weeks post-ovariectomy. Three weeks after treatment of hypoestrogen rats by the dose $18 \mathrm{mg} / 200 \mathrm{~g} \mathrm{~B}$.W, Eleutherine bulbosa extracts could decrease the systolic blood pressure level to $28.06 \%$, the diastolic to $30.47 \%$. Lipid profile of Dose 3 also showed recovery of Triglyceride, LDL and also Total Cholesterol. Eleutherine bulbosa extracts could improve blood pressure of ovariectomized rats by controlling lipids profile level.

KEY WORDS: Hypoestrogen; Blood pressure; Dayak Onions; Eleutherinol; Naphtoquinone.

\section{INTRODUCTION}

Menopause is a condition of the cessation of menstrual cycles in women due to decreased estrogen hormone production. Decreased estrogen levels lead to increased production of TNF-a so that osteoclast formation increases and osteoporosis develops. In the plasma lipid profile, estrogen levels are directly proportional to high density lipoprotein (HDL). And inversely with the total cholesterol, triglycerides and low density lipoprotein (LDL) in plasma. In hypoestrogen conditions, there is an increase in total cholesterol, triglycerides and LDL, while plasma HDL levels decrease. This may increase the risk of atherosclerosis. The occurrence of atherosclerosis will increase the risk of hypertension (Hargrove et al., 1999; Mieszczanska \& Velarde, 2014)

Women who have menopause are prone to hypertension as a result of reduced estrogen hormone. Based on research conducted by the Join National Committee (JNC 7), women who have post menopause have a higher systolic pressure of 4-5 $\mathrm{mmHg}$ than women who are still in the premenopausal phase.
The most frequently applied therapy in treating postmenopausal symptoms (hypoestrogens) is by using hormone replacement therapy (HRT) which has agonist activity on all estrogen receptors in the body and is not selective, resulting in effects on organs such as breasts, and other reproductive organs (Goodman et al., 2011). Further treatment developed using Selective estrogen receptor modulators (SERMs) that work agonists on receptors in nonreproductive organs and antagonists in reproductive organs. Examples of widely used SERMs are raloxifene and tamoxifen (Pinkerton \& Thomas, 2014).

Dayak onion bulbs (Eleutherine bulbosa (Mill.) Urb.) which are from Iridacea family, contain eleutherinol compounds which have been reported that it can bind to estrogen receptors in silico study (Amelia et al., 2015). Considering the traditional use of this plant which has also been used to cure breast cancer, hypertension, diabetes mellitus, decreasing cholesterol, and stroke, it is expected that dayak onion bulbs could be alternative herb on the 
treatment of postmenopausal symptoms with parameters of lipid profile and blood pressure.

\section{MATERIAL AND METHOD}

\section{Chemicals and Reagents}

\section{Plant materials}

Dayak onion bulbs (Eleutherine bulbosa (Mill.) Urb) as the main material, was obtained from Palu, Central Sulawesi and determined by the Research Center for Natural resources of Tadulako University (Certificate of Determination No. 206/IPH.1.01/If.07/I/2016). This plant was harvested from Palu forrest in Central Sulawesi, Indonesia (Palu climate: average temperature $4.6{ }^{\circ} \mathrm{C}$, humidity $74 \%$, rainfall is average $587 \mathrm{~mm}$ per year, altitude 95 feet above sea level).

Preparation of Dayak onion bulbs extracts. The dried powder of Dayak onions bulbs (Eleutherine bulbosa (Mill.) L.) were extracted by maceration method using ethanol. Then the extract was concentrated by rotary evaporator (Eyela, Tokyo Rikakikai, Tokyo, Japan). The extractive value of ethanol from dried powder was calculated as \% w/w yield and was found to be $3.77 \%$.

Identification and quantification of eleutherinol content by TLC. A total of $20 \mathrm{~mL}$ sample solution $(10 \mathrm{mg} / \mathrm{mL})$ was spotted on a silica gel 60 F254 plate. The elution process was performed until the eluent reaches the finish line. Eluent composisition were toluene: ethyl acetate: format acid (5: 4: 0.2 ). The spot then was evaluated by Automatic Thin Layer Chromatography (TLC) sampler and TLC equipment identitiy (CAMAG, Switzerland).

Animals. White female Sprague-Dawley rats, aged $30 \mathrm{~d}$, were purchased from Indonesia National Institute of Health Research and Development. The animals were grouped and housed in polyacrylic cages and maintained under standard laboratory conditions [temperature $(25 \pm 2){ }^{\circ} \mathrm{C}$ ] with dark and light cycle $(12 / 12 \mathrm{~h})$ and allowed free access to commercial pellet diet and water ad libitum. This research had been certified by ethical certification of Faculty of Medicine, University of Indonesia (UI FM No. 44/UN2.F1/ Ethics/2017) for the use of animals in experiments.

In this study, ovariectomy was performed on 30 female rats and SHAM on 6 others female rats. These rats were divided into 6 groups. Group 1 is sham group, group 2 as negative control group which received $0.5 \% \mathrm{CMC}$, group 3 as positive control group received a dose of tamoxifen of
$0.36 \mathrm{mg} / 200 \mathrm{~g} \mathrm{BW}$ of rats, group 3, 4, and 5 are groups who received $70 \%$ ethanolic extracts of Eleutherine bulbosa bulbs suspended in $0.5 \%$ CMC with doses $8 \mathrm{mg}$; $12 \mathrm{mg}$; and $18 \mathrm{mg} / 200 \mathrm{~g} \mathrm{BW}$ of rats.

Measurement of Blood Pressure. Blood pressure measurements were performed with a non-invasive blood pressure gauge CODA $®$ (Kent Scientific corporation, USA). By this tool, we can measure six types of blood pressure parameters, namely systolic blood pressure, diastole, mean blood pressure, heart rate, blood volume, and blood flow.

Detection of Lipid Profile. Cholesterol, Triglyceride, LDL, HDL levels were determined by enzymatic colorimetric method using kit (DiaSys, Germany) and evaluated using spectrophotometer UV-Vis Shimadzu 1800 (Japan).

Statistical analysis. Statistics software (SPSS version 16.0) was used for statistical analysis. The data represented mean \pm standard error of the mean. Statistical calculations were analyzed by One-way ANOVA followed by multiple comparison tests. $\mathrm{P}$ value $<0.05$ were considered to be significant ( $\mathrm{P}$ denoted probability).

\section{RESULTS}

Evaluation of naphthoquinone content. The active component of dayak onion bulb extract was confirm by TLC and the result was shown in Fig. 1.

The spot corresponding to the extract gave a retardation factor of 0.87 . Identification of TLC profile of ethanol extract $70 \%$ of Dayak onion bulbs showed Rf value varied to $0.10,0.28,0.44$, and 0.87 . The addition of $10 \%$ $\mathrm{KOH}$ spray reagent in ethanol showed orange spot on TLC plate with Rf 0.87 as seen in Figure 1. This data indicated that the extract contained naphtoquinone derivate and we suggest as Eleutherinol.

Ovariectomy of rats. We evaluate the success of ovariectomy in rat model as shown in Figures 2 to 4 . Figure 2 showed that in SHAM, the estrous cycle have 4 phase as a normal condition this is not monitored in ovariectomy rat as shown in Figure 3.

We also confirmed the size and the weight of uterus as shown in Figure 4 and Table I. The ovariectomized rat has smaller and lighter uterus compared with Sham group. This data indicated that ovariectomy was success.

The effects of dayak onion bulbs extract on blood 

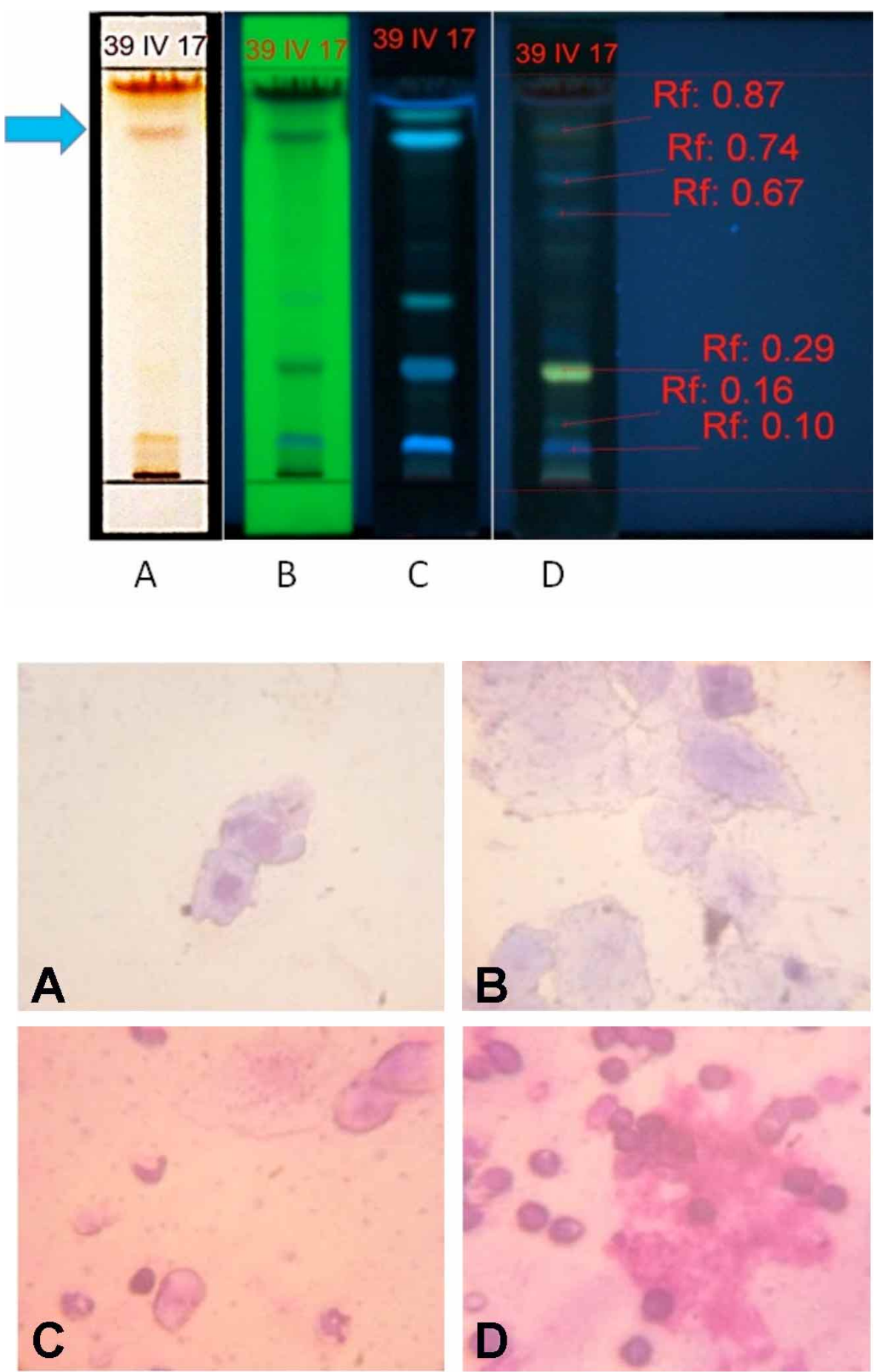

Fig. 1. TLC of E. bulbosa extracts. The Naphthoquinone (blue arrow) was identified by $0.5 \mathrm{~N} \mathrm{KOH}$ spray and was given orange band at the Rf 0.87. A. After sprayed by $0.5 \mathrm{~N} \mathrm{KOH}$ by visible; B. Before spray by UV $254 \mathrm{~nm} ; \mathrm{C}$. Before spray by UV $366 \mathrm{~nm}$; D. After sprayed by 0.5 $\mathrm{N}$ KOH by UV $366 \mathrm{~nm}$.

Fig. 2. Observation of vaginal swabs of sham SHAM for Estrous cycle. Note: (a) day 1 of the proestrous phase, (b) day 2 of the estrous phase, (c) day 3 of the metestrous phase, (d) day 4 diestrous phase. Observations were made at $40 \mathrm{x}$ magnification.

Table I. The weight of Uterine of Sham group and ovariectomized group.

\begin{tabular}{lcc}
\hline & SHAM $(\mathrm{g})$ & OVX $(\mathrm{g})$ \\
& Average \pm SD & Average \pm SD \\
\hline Uterine weight $(\mathrm{g})$ & $1.51 \pm 0.18$ & $0.34 \pm 0.03$ \\
Body weight gain $(\mathrm{g})$ & $35.58 \pm 11.35$ & $50.58 \pm 13.35$ \\
\hline
\end{tabular}




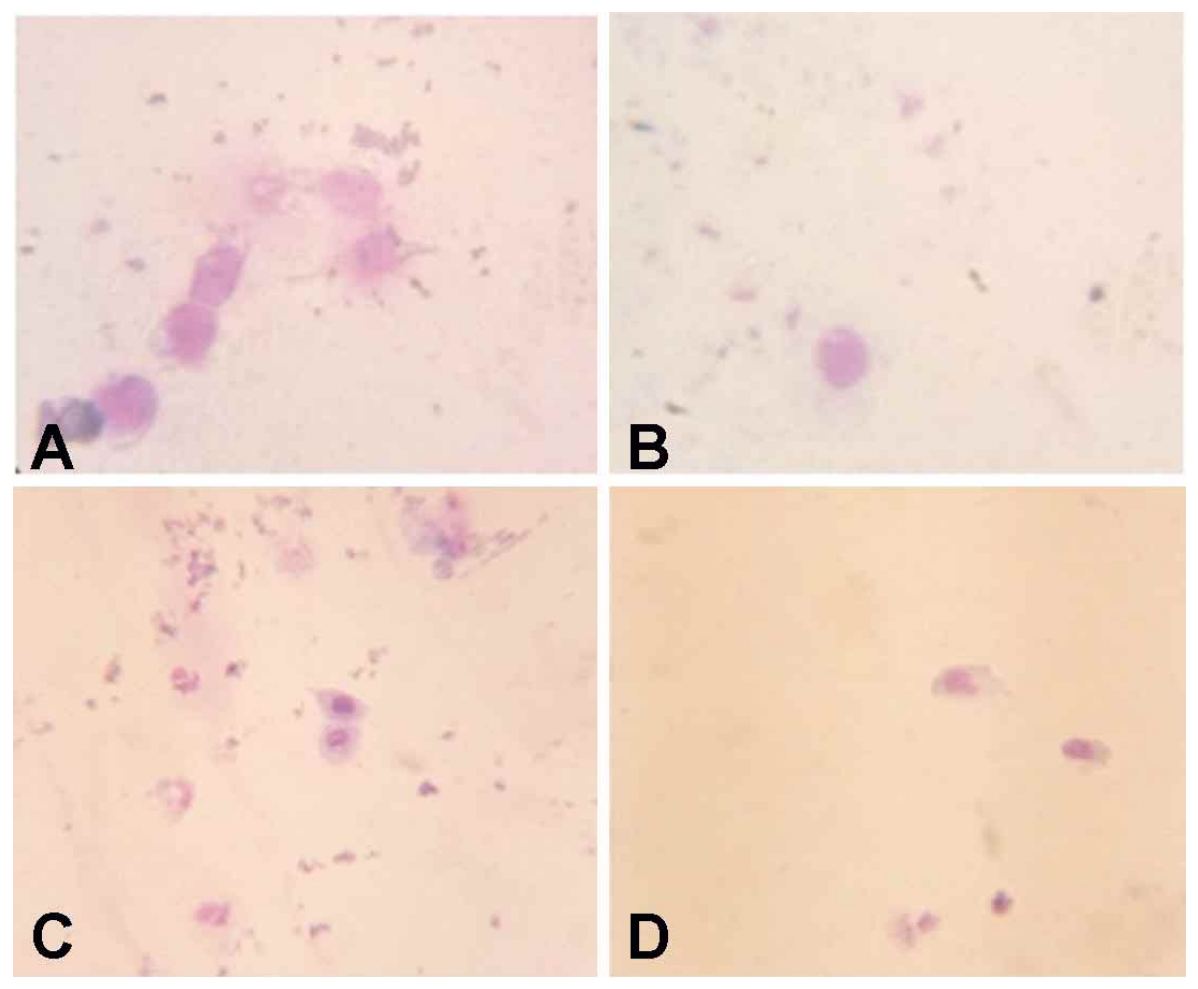

Fig. 3. Observation of vaginal swabs of the ovariectomized group for Estrous cycle after ovariectomy. Note : Observation of the vaginal swab for four consecutive days of ovariectomized group showed no difference in phases (a) day 1 , (b) day 2, (c) day 3, (d) day 4. Observations were made at $40 \mathrm{x}$ magnification.

Table II. The Alteration of Systolic pressure after 3 weeks treatment.

\begin{tabular}{lccc}
\hline Groups & \multicolumn{2}{c}{ Systolic Pressure $(\mathrm{mmHg})$} & Decrease in systolic \\
& Before & After & BP \\
\hline Sham & $120.83 \pm 10.48^{*}$ & $114.67 \pm 4.93$ & $-1.18 \pm 8.17$ \\
Negative control & $175.33 \pm 5.82^{\#}$ & $169.67 \pm 5.12$ & $1.93 \pm 2.02$ \\
Positive control & $161.00 \pm 5.69 \#^{*}$ & $141.17 \pm 1.60$ & $16.48 \pm 2.61$ \\
Dose I & $153.33 \pm 9.48 \#^{*}$ & $139.00 \pm 4.56$ & $10.28 \pm 5.07$ \\
Dose II & $159.33 \pm 2.73 \#^{*}$ & $133.00 \pm 1.67$ & $19.43 \pm 4.13$ \\
Dose III & $164.67 \pm 5.89 \#^{*}$ & $123.17 \pm 4.83$ & $28.06 \pm 5.66$ \\
\hline
\end{tabular}

Note: Sham = CMC $0.5 \%$, negative control $=$ CMC $0.5 \%$, positive control $=$ tamoxifen $0.36 \mathrm{mg} / 200 \mathrm{~g}$ BW, Dose I = E. bulbosa extracts bulb $8 \mathrm{mg} / 200 \mathrm{~g} \mathrm{BW}$, Dose II = $12 \mathrm{mg} / 200 \mathrm{~g} \mathrm{BW}$, Dose III = $18 \mathrm{mg} /$ $200 \mathrm{~g} \mathrm{BW},(*)=\mathrm{p}<0.05$ compared with SHAM, $(\#)=\mathrm{p}<0.05$ compared with OVX

Table III. The Alteration of Diastolic pressure after 3 weeks treatment.

\begin{tabular}{lccr}
\hline \multirow{2}{*}{ Groups } & \multicolumn{2}{c}{$\begin{array}{c}\text { Diastolic Pressure }(\mathrm{mmHg}) \\
\text { Before }\end{array}$} & $\begin{array}{r}\text { After } \\
\text { Decrease in } \\
\text { diastolic BP }\end{array}$ \\
\hline Sham & $73.83 \pm 9.11^{*}$ & $87.67 \pm 8.16$ & $-17.60 \pm 18.95$ \\
Negative control & $130.00 \pm 27.28^{\#}$ & $141.33 \pm 14.29$ & $7.26 \pm 10.80$ \\
Positive control & $125.17 \pm 15.84 \#$ & $119.83 \pm 8.23$ & $15.94 \pm 10.85$ \\
Dose I & $126.00 \pm 16.54 \#$ & $111.17 \pm 8.68$ & $7.11 \pm 26.31$ \\
Dose II & $127.67 \pm 16.07 \#$ & $115.50 \pm 2.51$ & $8.22 \pm 12.88$ \\
Dose III & $132.67 \pm 10.69 \#$ & $91.83 \pm 12.32^{*}$ & $30.47 \pm 13.82$ \\
\hline
\end{tabular}

Note: Sham $=$ CMC $0.5 \%$, negative control $=$ CMC $0.5 \%$, positive control $=$ tamoxifen $0.36 \mathrm{mg} / 200 \mathrm{~g}$ BW, Dose I = E. bulbosa extracts bulb $8 \mathrm{mg} / 200 \mathrm{~g} \mathrm{BW}$, Dose II = $12 \mathrm{mg} / 200 \mathrm{~g} \mathrm{BW}$, Dose III = $18 \mathrm{mg} /$ $200 \mathrm{~g} \mathrm{BW},(*)=\mathrm{p}<0.05$ compared with SHAM, $(\#)=\mathrm{p}<0.05$ compared with OVX. 
Table IV. Measurements of Lipid profile of ovariectomized rats after 3 weeks treatment.

\begin{tabular}{lcccc}
\hline Groups & Triglyceride $(\mathrm{mg} / \mathrm{dL})$ & Total Cholesterol $(\mathrm{mg} / \mathrm{dL})$ & HDL $(\mathrm{mg} / \mathrm{dL})$ & LDL $(\mathrm{mg} / \mathrm{dL})$ \\
\hline Sham & $145.76 \pm 32.70 \#$ & $232.43 \pm 56.37$ & $60.99 \pm 5.65$ & $142.28 \pm 57.25 \#$ \\
Negative control & $270.02 \pm 18.08^{*}$ & $394.31 \pm 51.33^{*}$ & $65.19 \pm 19.81$ & $275.12 \pm 36.58^{*}$ \\
Positive control & $214.74 \pm 55.07^{*}$ & $309.17 \pm 16.61^{*}$ & $55.89 \pm 4.57$ & $210.33 \pm 25.57^{*} \#$ \\
Dose 1 & $207.02 \pm 54.31^{*} \#$ & $330.16 \pm 10.09^{*}$ & $63.13 \pm 11.29$ & $225.63 \pm 13.83^{*}$ \\
Dose 2 & $188.21 \pm 26.33 \#$ & $270.74 \pm 16.49^{*}$ & $60.95 \pm 15.09$ & $172.16 \pm 22.36 \#$ \\
Dose 3 & $160.63 \pm 28.94 \#$ & $233.07 \pm 17.78$ & $56.27 \pm 2.71$ & $144.68 \pm 15.63 \#$ \\
\hline
\end{tabular}

Note: Sham $=\mathrm{CMC} 0,5 \%$, negative control $=\mathrm{CMC} 0,5 \%$, positive control $=$ tamoxifen $0,36 \mathrm{mg} / 200 \mathrm{~g}$ BW, Dose $1=$ E. bulbosa extracts bulb $\mathrm{lb} 8 \mathrm{mg} /$ $200 \mathrm{~g} \mathrm{BW}$, Dose $2=12 \mathrm{mg} / 200 \mathrm{~g}$ BW, Dose $3=18 \mathrm{mg} / 200 \mathrm{~g} \mathrm{BW},\left(^{*}\right)=\mathrm{p}<0.05$ compared with negative control, (\#) $=\mathrm{p}<0.05 \mathrm{compared}$ with sham.

pressure. The ovariectomy could increase systolic and diastolic blood pressure 4 weeks after ovariectomy. compared with SHAM as shown in Table II and Table III.

There was significant difference in systolic blood pressure between extracts treatment group and negative control group at one week after treatment while, there was no significant difference between diastolic blood pressure between treatment group and negative group. There was a difference in both systolic and diastolic blood pressure after two weeks of treatment compared to a condition before treatment. The results in Table II and III showed that in the third week after treatment there was no significant difference in systolic and diastolic blood pressure between the groups given Dayak dose 3 bulb extract and sham group.

The effects of dayak onion bulbs extract on serum lipid profiles. Table IV showed that ovariectomy resulted increases in all the lipids except for HDL. All the treatment with active drug in the control group reduce lipids in the ovariectomized rat.

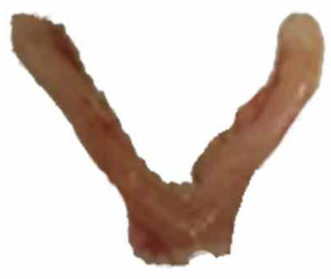

A

Fig. 4. The size of Uterine of Sham group (a) and ovariectomized group (b)

\section{DISCUSSION}

Analysis of Naphtoquinone by Thin Layer Chromatography. The TLC method was successfully identified the content of the Dayak onion extracts. TLC is a method that is used to separate a mixture of compounds. The choice of stationary phase and mobile phase will affect the migration of compounds through the stationary phase. A very soluble compound in the mobile phase will move up more quickly, compared to a compound that is less soluble which is influenced by many factors and is quite characteristic of compounds. We separated naphtoqunone by methanol:chloroform (7:1) and identified by chromogenic spray $0.5 \mathrm{~N}$ Potassium hydroxide. When sprayed with alcoholic potassium hydroxide, the green fluorescence changed to an orange fluorescence.

Analysis of Blood Pressure. At one week after treatment there was a significant difference in systolic pressure between dayak onion bulbs extract and OVX, while there was no significant difference in diastolic pressure between dayak onion bulbs extract and OVX. Both systolic and diastolic pressure in the treatment group had a significant difference $(\mathrm{p}<0.05)$ with the SHAM at the two weeks after treatment. In the third week after treatment, there was no significant difference in systolic and diastolic blood pressure between the groups given the dayak onion bulbs extract dose III and SHAM. This suggests that administration of dose III dayak onion bulb extract could lower both systolic and diastolic blood pressure to normal blood pressure after three weeks of treatment. Hypoestrogen increased blood pressure due to increase of a vasoconstrictor NPY and decrease of vasodilator neuropeptides (Di Carlo et al., 2007).

Analysis of lipids profile. From the data obtained, it could be seen that the administration of dayak onion bulbs extract could decrease the lipid profile of hypoestrogenic rat. This was due to the compounds contained in the dayak onion bulb extract of eleutherinol could bind to the estrogen receptor and caused some estrogenic effects, which estrogen could increase the activity of LDL receptors in the liver and increase liposis (Hangrove et al., 1999). Giving tamoxifen in animal showed that tamoxifen did not give significant effect to decrease of total cholesterol, LDL and 
triglyceride, and decrease in blood pressure both systolic and diastolic. This result is relevant with previous study which proves that tamoxifen does not significantly reduce total cholesterol, LDL, and triglyceride levels in the blood because they have oncoprotein MUC-1 that can resistance to tamoxifen (Radwanska, 1993). Therefore does not significantly affect the cardiovascular system.

Furthermore, the decrease in blood pressure both systolic and diastolic occurred due to the presence of eleutherinol compounds contained in bulbs extract of Dayak onions, which are estrogen agonists. The decrease in blood pressure was thought to be due to a decrease in blood lipid profile, preventing atherosclerosis and decreasing blood pressure of hypoestrogen rat (Mieszczanska \& Velarde).

\section{CONCLUSION}

The $70 \%$ ethanolic extract of dayak onion bulbs could reduce blood pressure by reducing lipid profile of hypoestrogenic model rat.

BAHTIAR, A. \& CHUMALA, D. Y. Extractos de bulbos de Cebollas Dayak (Eleutherine bulbosa (Mill.) Urb.) reducen la presión sanguínea en un modelo hipoestrogénico en ratas controlando el perfil lipídico. Int. J. Morphol., 36(3):1016-1021, 2018.

RESUMEN: Para determinar los efectos del $70 \%$ de extracto etanólico de Eleutherine bulbosa (Mill.) L. en bulbos que contenían naftoquinona, se analizó la presión arterial de ratas ovariectomizadas. Se realizó un estudio de cromatografía de capa fina para analizar el contenido de los extractos de bulbos de Eleutherine bulbosa (Mill.) usando cloroformo:metanol (7:1) como diluyente. En este estudio se utilizaron ratas blancas Sprague-Dawley hembras, que se dividieron en 6 grupos: SHAM y OVX, ambos grupos fueron administrados con carboximetilcelulosa al 0,5\%; grupo control positivo, recibió tamoxifeno (0,36 mg / $200 \mathrm{~g}$ de B.W.); y tres grupos restantes, que recibieron tres dosis diferentes de extracto, es decir, dosis 1 , 2 y 3 a las que se les administró 8, 12 y $18 \mathrm{mg} / 200 \mathrm{~g}$ de por peso, respectivamente el día 29 hasta el día 50. Todos los grupos fueron sometidos a ovariectomía en el día 1, excepto el grupo simulado. La medición de la presión arterial se realizó el día anterior a la ovariectomía con la herramienta no invasiva CODA ${ }^{\circledR}, y$, posteriormente, en la segunda, tercera y cuarta semanas de realizada la ovariectomía. Tres semanas después del tratamiento aplicado a las ratas hipoestrógenas, con la dosis de $18 \mathrm{mg} / 200 \mathrm{~g}$ por peso, los extractos de Eleutherine bulbosa podrían disminuir el nivel de presión arterial sistólica al 28,06 $\%$, y la diastólica al 30,47 \%. La dosis 3 del perfil lipídico mostró mejoría en los niveles de Triglicéridos, LDL y Colesterol Total.
Los extractos de Eleutherine bulbosa podrían mejorar la presión sanguínea de ratas ovariectomizadas controlando el nivel del perfil lipídico.

PALABRAS CLAVE: Hipoestrógeno; Presión sanguínea; Cebollas Dayak; Eleutherine; Naftoquinona.

\section{REFERENCES}

Amelia, T.; Pratiwi, D.; Romsiah, \& Tjahjono, D. H. In Silico Study of The Component of Eleutherine americana MERR. on Human Estrogen Reseptor Alpha as Potential Anti-Breast Cancer. Paris, $3^{\text {rd }}$ International Conference on Computation for Science and Technology (ICCST-3), Atlantis Press, 2015.

Di Carlo, C.; Di Spiezio Sardo, A.; Bifulco, G.; Tommaselli, G. A.; Guerra, G.; Rippa, E.; Mandato, V. D. \& Nappi, C. Postmenopausal hypoestrogenism increases vasoconstrictor neuropeptides and decreases vasodilator neuropeptides content in arterial-wall autonomic terminations. Fertil. Steril., 88(1):95-9, 2007.

Goodman, N. F.; Cobin, R. H.; Ginzburg, S. B.; Katz, I. A.; Woode, D. E. \& American Association of Clinical Endocrinologists. American Association of Clinical Endocrinologists Medical Guidelines for Clinical Practice for the diagnosis and treatment of menopause. Endocr. Pract., 17 Suppl. 6:1-25, 2011.

Hargrove, G. M.; Junco, A. \& Wong, N. C. Hormonal regulation of apolipoprotein AI. J. Mol. Endocrinol., 22(2):103-11, 1999.

Mieszczanska, H. Z. \& Velarde, G. P. Management of Cardiovascular Disease in Women. Berlin, Springer-Verlag, 2014.

Pinkerton, J. V. \& Thomas, S. Use of SERMs for treatment in postmenopausal women. J. Steroid Biochem. Mol. Biol., 142:142-54, 2014.

Corresponding author:

Anton Bahtiar

Department of Pharmacology

Faculty of Pharmacy

Universitas Indonesia

Depok 16424 West Java

INDONESIA

Email: anton.bahtiar@ui.ac.id

Received: 21-11-2017

Accepted: 26-03-2018 